\title{
The European Debate on the Single Employment Contract
}

\section{The Debate in Italy: The Italian Flexicurity. The Italian White Book on Labour. Act No 1481/2009 for the Transition to Flexicurity and the Single Employment Contract}

$Y_{\mathrm{n}}$ Italy, the rethinking of the relationship between employment protection and labour market is highly topical, although dating back over time. The theme is part of "the safety valves reform" (invoked several times, but never really implemented) according to proposals ranging from variously articulated theories of a decisive shift towards the protection of the market ${ }^{1}$ - as indicated by the law n. 848 of 2002 for the reform of the labour market ${ }^{2}$ - based on the distinction between the income support to suspended workers (redundancy payment or Cassa Integrazione Guadagni) and interventions of income support for unemployed workers as a result of job loss (unemployment) ${ }^{3}$.

* Professor, ILO. Secretary General of the International Society of Labour and Social Security Law based in Geneva. A member of several European and international research and scientific committees.

${ }^{1}$ See Libro Bianco sul mercato del lavoro in Italia. Proposte per una società attiva e per un lavoro di qualità, Ministero del lavoro e delle politiche sociali, Roma, ottobre 2001; about this project see v. M. Biagi, Competitività e risorse umane: modernizzare la regolazione dei rapporti di lavoro, "Rivista Italiana di Diritto del Lavoro" 2001, p. 257 ff; P.G. Alleva, E. Ballettim, U. Carabelli, A. Di Stasi, N. Forflani, F. Liso, M. Pacui, Tutela del lavoro e riforma degli ammortizzatori sociali, Giappichelli, Torino 2002. See also G. Casale, A. Perulli, Towards the Single Employment Contract, Hart Publishing, Oxford, ILO, Geneva 2014.

${ }_{2}$ On the matter, see M. Cinelli, Riforma del mercato del lavoro e welfare, "Rivista del Diritto e della Sicurezza Sociale" 2006, vol. 17; idem, "Nuovi lavori" e tutele: quali spazi per la previdenza sociale?, "Rivista Italiana di Diritto del Lavoro" 2005, p. 225; R. Pessi, Tutele previdenziali e tutele assicurative nello scenario dei nuovi modelli negoziali, "Rivista del Diritto e della Sicurezza Sociale" 2006, p. 39; G. Sigillò Massara, Ammortizzatori sociali di fonte collettiva e fondi di solidarietà nella riforma del Welfare, Cedam, Padova 2008, p. 154 ff.

3 See A. Di Stasi, Gli ammortizzatori sociali tra "il cielo delle idee" e le più recenti novità legislative. Una introduzione, "Rivista Giuridica del Lavoro e della Previdenza Sociale" 2011, 
The road of this rethinking is rich in never implemented reforms. As it is known, the White Paper on the labour market in Italy of autumn 2001, and the resulting bill No 848 of 2002 (then eliminated in the d.d.1. n. 848 bis), indicated a profound perturbation of labour protection, with forecasts ranging from the overcoming of real protection (Article n. 18 of the Workers' Statute) accompanied by a proper review of the safety measures, to the reforms of the labour market and labour inspection services. In essence, the new design intended to extend the minimum level of protection provided by the safety measures, increasing them at the European levels of expenses to be financed by contributions, overcoming the logic in favour of a purely welfare system, hence focusing on protection mobility and reintegration into the labour market ${ }^{4}$ of the workers.

The ambitious reform, abandoned because of the radical opposition mounted by the CGIL (the largest national trade union confederation), suffered, however, the limit of prospecting a "zero cost" funding, by a rationalization of the rates system for the financing of the safety measures. The reform was very much criticized by many ${ }^{5}$.

A few years later, in perspective of a legal policy that was intended to strengthen the second element through rationalisation of the existing institutions, the legislator, with the Law 247/2007, had assigned to the Government the task of issuing decrees in order to reform the system of safety measures by creating two instruments of income support.

The first is about unemployment, and it is aimed at harmonizing the mobility institutions and that of the unemployment benefit, through the creation of a unique form of protection, aimed at supporting the income and bringing the unemployed back to work; the second is relative to the income support in cases of suspension of the employment relationship by extending an universal treatment of wage capable to overcome the distinction between ordinary and extraordinary redundancy payment (Cassa Integrazione Guadagni Ordinaria o Straordinaria) 6 .

p. $339 \mathrm{ff}$. and there some forwards to other intervantions on the theme "Gli ammortizzatori sociali oggi".

${ }^{4}$ See M. Tiraboschi, Il sistema degli ammortizzatori sociali: spunti per un progetto di riforma, [in:] M. Tiraboschi (a cura di), La riforma Biagi del mercato del lavoro, Giuffrè, Milano 2004, p. $1105 \mathrm{ff}$.

${ }^{5}$ See C. Lagala, La previdenza sociale tra mutualità e solidarietà. Percorsi nel sistema pensionistico e degli ammortizzatori sociali, Cacucci, Bari 2001.

${ }^{6}$ See F. Liso, Brevi appunti sugli ammortizzatori sociali e sui servizi all'impiego nel protocollo del 23 luglio 2007, [in:] A. Perulli (a cura di), Le riforme del lavoro. Dalla legge finanziaria 2007 al Protocollo sul Welfare, Halley editore, Matelica 2007, p. 110; G. Sigillò Massara, Ammortizzatori sociali di fonte collettiva..., p. 170; G. Gentile, La riforma degli ammortizzatori sociali, [in:] M. Cinelli, Ferraro G. (a cura di), Lavoro, competitività, welfare. Commentario alla legge 24 dicembre n. 247 e riforme correlate, UTET, Torino 2008, p. 488 ff. 
The reform was accompanied by policies to strengthen the active employment policies that promote the stabilization of employment relationship, the rise in employment rates for women and youth, and the reintegration in the labour market of workers who are most in need of protection ${ }^{7}$. But the issue of flexicurity, as understood at the "European" level, was welcomed by the Italian labour-policy debate only in a de jure condendo perspective, thanks to the reform policies of the draft Law n. 1418 (at the initiative of Senator Pietro Ichino and others ${ }^{8}$ ), an ambitious response to the dual segmented Italian labour market, described by Ichino as "cittadella degli inclusi ed esercito degli eslcusi" ("citadel of the insiders and the army of the outsiders") ${ }^{9}$.

As stated in the report to the Ichino bill, a modern country cannot resign itself to the trend of today's labour market, which is a source of unfairness (precarious jobs in a long-term) and inefficiency (discouraging investment in stabilising precarious workers).

These reasons, exacerbated by the global economic crisis, brought about the following comment "if the law remains the current one, in the next two or three years of great uncertainty, most of the hundreds of thousands of people who are losing their old job due to the crisis, may find a job, but if found it, this will be the most unstable and least protected job"10.

This is because, in times of economic crisis and uncertainty in the future, companies are held back from making new hires with a guaranteed stability. The Ichino's bill, composed of 7 articles, seems to follow the substance of the proposal already advanced in France by the economists Cahuc and Kramarz, implemented by the government across the Alps in a document in which the need to reduce the segmentation of the labour market through the creation of a single contract of employment and the need to change "le régime du CDI fréquemment considéré comme un frein à l'embauche" was stressed. In the Italian bill it is proposed to balance the conflicting requirements of flexibility (by the employer) and safety (by the worker), with a balanced mix of law and collective agreements (see Art. 2, co. 1). The purpose is expressly declared: "to reconcile, the greatest possible, flexibility for production facilities [...] with the highest possible security and with equal opportunities for all workers", who are eligible for a permanent contract if there is a "position of substantial dependence" (art. 2, para. 1, Lett. a).

${ }^{7}$ See M. Rosano, Il riordino dei servizi per l'impiego, [in:] M. Cinelli, G. Ferraro (a cura di), Lavoro, competitività...

8 DDL, 25 March 2009.

9 On the ddl in exam, see D. Gottardi, Osservazioni alla proposta di Pietro Ichino, "Rivista Italiana di Diritto del Lavoro" 2009, III, $114 \mathrm{ff}$.

10 See the relations to the $\mathrm{ddl}$ n. 1481, also published in "Rivista Italiana di Diritto del Lavoro" 2009, Giuffrè Editore, III, 97. 
This reform has four methodological principles: 1) the overcoming of the old regime should take place gradually, according to the layering ${ }^{11}$ method, or by the application of the new regime only to cases that come into existence at a certain moment; 2) the application of the try-and-go method, according to which the law acts as guideline and the actual trial is conducted by the enterprise and by the trade union, as the prospect of reform is based on an agreement between the parties concerned; 3) the creation of a system that is not based on public resources, but on its ability to create an industrial relations system, without costs for the community, and is able to relocate outgoing workers and to attract new ones; 4 ) considered that the system provided by public services of training and job placement cannot be effective in responding to the needs of the labour market, enterprises would be incentivised to apply efficient policies.

The core of the reform is the introduction of the so-called collective agreement of transition to the new system of job protection provided by art. 2, in which "a group of enterprises and one or more trade unions [...] establish a bilateral body with a joint management, or a consortium between them, in order to ensure that newly hired workers, in case of loss of employment, would have an income support and an intensive care in the labour market, following standards not lower than those indicated in art. 3".

As already mentioned, this protection system, applicable to workers employed at a certain time, can also be applied to all the relationships already established in the enterprise, provided that it is endorsed, either:

a) by a trade union or coalition of trade unions that, in the most recent election of union representatives extended to all the enterprise workers, within the last three years, has achieved a total of more than half of the votes received;

b) by a trade union or by a coalition of trade unions which, although not satisfying the requirement in para a), has submitted the collective agreement to a prior referendum to all workers and has received more votes than the total half of the votes provided (Article 2, paragraph 4).

Because of its special nature, the "transition contract", to take effect, must be published prior to a deposit at the CNEL (National Economic and Labour Council).

Art. 3 of the bill regulates the agreement on work relocation (Contratto di ricollocazione al lavoro) between the bilateral body or the consortium and the worker. This applies to workers who have successfully completed one year of seniority, who were dismissed for justified objective reasons,

${ }^{11}$ See G. Saint Paul, On the Political Economy of Labour Market Flexibility, "NBER Macroeconomic Annual" [Cambridge Mass., Mit Press] 1993. 
or for disciplinary reasons declared illegal by the court. This contract involves the provision of a complementary treatment for up to four years, which amounts to $90 \%$ of the last salary for the first year, $80 \%$ for the second, $70 \%$ for the third and $60 \%$ for the fourth (with reference, however, to a maximum annual salary of $€ 40,000$ ).

This system, inspired by the Danish experience, means that even if the worker remains unemployed for the four years, the total compensation payable will be equal to three annual wages $(90 \%+80 \%+70 \%+60 \%=$ $300 \%$ ) but, since the annual wages remain on the employer's social security contributions, the total cost of dismissal is limited to 2 annual wages.

The bilateral body or the consortium are then required to assure an intensive care provision in the search for new jobs and in the provision of training and retraining initiatives aimed at finding job opportunities that actually exist and are in relation to the worker's capacities.

In parallel, workers have an obligation to make themselves available for re-qualification initiatives and for starting the new job, with a work timetable equal to that charged before the dismissal. The work done is subject to the entity's power of direction and control, which is exercised through a tutor.

If, however, the employee has passed the trial period, but not the first year of service, the bilateral body or the consortium is obliged to offer the conclusion of the relocation contract, except the provision about the supply of a complementary treatment, as stated in Art. 3, para. a).

The worker is free to withdraw from the relocation contract, even without notice, while the bilateral body may terminate the contract if the status of unemployment is finished, or when the worker, without justification, refuses a job opportunity or to follow professional training or retraining.

Based on the provisions of art. 4, the bilateral body or the consortium are funded through the contributions of the enterprise or a group of enterprises that have signed the founding contract, and contributions from the European Social Fund and the respective region. Each enterprise must give a guarantee for their workers' credits with the bilateral body or the consortium, in case of closure.

With regard to business or production units (small enterprises) who do not fall within the scope of art. 18 of the Workers Statute, a contribution of $0.5 \%$ of workers' gross wages which are subject to the new regime of protection was imposed by the Treasury.

Under the new system of protection, along the lines of the Northern Europe model, the bill proposes a new discipline of dismissal. In this context, the worker's dismissal for economic or organizational reasons (art. 7) is subject to the monetary cost by the enterprise for workers' compensation. 
Under this bill's proposal, not only the traditional worker (art. 2094 cc), but also the provider of work services who works on a continuous basis and receives more than two thirds of the income from the same enterprise is covered by the new security provisions. The only exception is made for "the work performed in a position of autonomy and that at least one of the two following requirements are met: a) the gross annual salary exceeds 40,000 Euro b) the person in question is registered to the Bar, or to another professional order which is incompatible with the position of workers" (Article 5).

In this case the employee is still employed under a permanent contract, except in cases provided for by the transition contract or the collective agreement applicable in the production unit, or in other specific cases ${ }^{12}$. On this point, the Ichino's proposal follows the philosophy of the "single contract of employment", advanced by Boeri and Garibaldi, following the French and Spanish examples ${ }^{13}$. As we have seen above, the single employment contract tries to avoid the typological fragmentation of the contracts which is a characteristic of the segmented labour markets in a number of European countries. By introducing a "single contract" (p.d.1. n. 2630/09 and d.d.1. n. 2000/10), the scheme is characterized by an entry period of three years during which, in case of dismissal, the only protection is a monetary one. After the three years, the consolidation of the contract would mean a stable and permanent employment, subject to the current labour legislation.

In the Ichino's proposal, however, the real stability for illegal non-disciplinary dismissal would be permanently banned in favour, as mentioned above, of an economic compensation. In other words, the two mentioned proposals are different in terms of workers' protection.

The adoption of a single employment contract does not automatically mean a full protection in the labour market.

Enterprises could, in fact, practice a systematic withdrawal from the single employment contract before the end of the three years period, and they can renew the contract, so that a new period of free dismissal can apply. To avoid such a result, it would be necessary to provide a legal limit similar to that laid down for the fixed-term contract, which is the prohibition of renewal or repetition of the same contract more than once.

${ }^{12}$ Seasonal contract, contract signed to replace another employee whose relationship is temporarily suspended for any reason, the assumptions of shows or a theater season, the recruitment for fairs, markets and other trade events of a temporary nature, or other requirements for general guidance only occasional or extraordinary, assumptions with a term contract of not less than three years for scientific or educational activities cannot be classified as contracts of indefinite duration.

${ }^{13}$ See T. Boeri, P. Garibaldi, Un nuovo contratto per tutti, Chiarelettere, Milano 2008, and also "Il testo unico del contratto unico", 19.10.2009, in http:www.lavoceinfo.it. 
Somehow, the single employment contract does not ensure the elimination of a segmentation of the labour market and the end of precarious work. It is easily possible that a worker hired to work with the single employment contract, after having agreed to enter into the contract with an end period of three years, is forced to enter into another single contract with a different employer, and this situation can be replicated several times, thus confirming the precarious status.

In this respect, it is not at all certain that the approach of the single employment contract represents a better choice than the fixed-term contract, neither in terms of enterprise desirability, nor in terms of social inclusiveness ${ }^{14}$.

As Carinci suggested, it should also be noted that until now, the legislative choice has been focused on distinguishing different types of contracts. From now on, we have also to consider the new article n. 8 of the decree law n. 138/2011 (now law n. 148/2001) - not yet really enforced or well understood ${ }^{15}$ which allows the local bargaining level to derogate from the national bargaining level.

Moreover, as it has been observed, a similar result intended by the single employment contract could be achieved by extending the duration of the trial period (incurring the six months maximum foreseen by art. 10, 1. n. 604/66) and providing the conditions for termination of employment over a longer period of time than the one currently applied.

The challenge of overcoming the segmentation of the labour market is then put back in a mere choice of business administration (the consolidation of the contract) that the enterprise would be encouraged to do because of its investment in "human capital" through education and vocational training.

In fact, only if the enterprise decides not to waste the investment made in human capital, the labour market would self-regulate itself spontaneously, converging toward the single employment contract, because of greater opportunities and of mutual interests.

On the contrary, the Ichino bill proposal, differently from the perspective of the single employment contract, provides a substantial elimination of dismissal judicial review, by distinguishing between disciplinary and discriminatory dismissal (Article 6), on the one hand, and dismissal for economic and organisational reasons (Article 7), on the other.

The application of art. 18 of the Workers' Statute would be limited to disciplinary dismissal (unfair) and to that imposed for a discriminatory

${ }^{14}$ See P. Tullini, Proposte di revisione della disciplina del lavoro flessibile, [in:] G. Ciocca (a cura di), Le trasformazioni del mercato del lavoro, EUM, Macerata 2011, p. 35.

15 See F. Carinci, "Provaci ancora, Sam": ripartendo dall'art. 18 dello Statuto. Play it again, Sam: recent draft laws on art. 18 st. lav", WP C.S.D.L.E. “Massimo D'Antona” 2012, IT - 138. 
reason, or on a whim. However, the real protection guaranteed is even tempered by providing the opportunity, to the judge, to order only the reinstatement in the workplace with zero or reduced compensation for damages, or only with damages' compensation. All in all, the reinstatement of the dismissed worker is still excluded in small enterprises.

According to Ichino's proposal, the novelty of the discipline of dismissal for economic and organisational reasons is based on the notion of objective justification, understood as the expected loss for the entrepreneur higher than a certain threshold, in case the employment relationship should continue.

The best way to protect the worker from an illegitimate dismissal appears to be, based on what is stated explicitly, not the judicial review of reasons for the termination of employment, but rather, the imposition of a monetary cost on the entrepreneur that is equal to the loss expected and considered appropriate by policy makers ${ }^{16}$.

At the time of the dismissal notice, as stated by the provisions of paragraph 2, the enterprise must provide an amount equal to as many twelfths of the gross pay as received in the last year, for every year of work done, less the salary corresponding to the notice period which is due to the worker. The second component of the damage should be covered, however, by unemployment insurance provided by a bilateral body or a consortium.

In this perspective, the exemption from the judicial review of dismissal dictated by economic reasons does not mean "free dismissal": "the entrepreneur's choices are subject to an automatic filter, consisting of the cost of redundancy - the "firing costs" which is much more effective and less onerous for both parties, than what can be expected by the judicial procedures"17.

In addition, the report to the bill, in the section entitled "On the matter of the constitutionality and community legitimacy of the exemption of the economic justification of dismissal from judicial control", provides explanations and defences to any questions of constitutional legitimacy, including the principle of absolute immunity of the economic-organisa-

${ }^{16}$ In this sense, see O. Blanchard, J. Tirole, Contours of Employment Protection Reform, trad. It., "Profili di riforma dei regimi di protezione del lavoro", "Rivista Italiana di Diritto del Lavoro" 2004, I, p. 161 ff. Art. 5, par. 5, precises that "le esigenze economiche ed organizzative che motivano il licenziamento non sono soggette a sindacato giudiziale, salvo il controllo, quando il lavorator ne faccia denuncia, circa la sussistenza di motivi discriminatori determinati, o motivi di mero capriccio, intendendosi per tali motivi futili totalmente estranei alle economiche, organizzative o produttive aziendali". If, however, the dismissal has been imposed to an employee who has completed 20 years of service, the company, given the increased protection against the older worker, will have to provide the justified economic, technical, organizational reason for dismissal.

17 See P. Ichino, Inchiesta sul lavoro, Mondadori 2011, p. 124. 
tional business that is very often overlooked by the courts, a behaviour that can be considered unconstitutional.

In addition, the ILO Convention n. 158/1982 on termination of employment provides a compensation for the workers dismissed without a justified reason. The Ichino's proposal, on this point, provides a compensation for all workers that are dismissed for economic-organisational reasons, regardless of the legitimacy of the dismissal, providing a greater protection than the one required by international standards.

The reform proposed by Ichino has generated criticism and objections from various sides. Some critics of the single employment contract emphasize the irrational belief that they can limit the complex reality of modern ways of working and producing in a single bargaining scheme, banning coordinated and continuous collaborations, even if genuine, compressing the cases of fixed-term contracts into rigid assumptions, in a poorly characterized perspective for a monetisation in exchange for freedom of dismissal ${ }^{18}$.

According to this perspective, the unnecessary introduction of the single employment contract is evidenced by the presence, in the Italian system, of the apprenticeship contract, which already represents the first stage in the labour market, before getting a contract without a limit of time. In principle, at the end of the apprenticeship period, there is a strong possibility of securing the employer relationship because of the interest of the enterprise to keep the skilled workplace.

Different critics complain about the non-consideration of the context in which the reform should be implemented. In a scenario characterised by a deep economic crisis, it is rather necessary to focus on some immediate measures, and the strengthening of administrative resources, in order to avoid anti-crisis measures that are resolved only through welfare interventions ${ }^{19}$.

In Carinci's opinion ${ }^{20}$, for example, the introduction of a single employment contract in Italy would have some systematic consequences which would not be so consistent with the present order of labour laws. He defined its impact as "unsustainable". He pointed out that an open-ended contract, which has not an obligation of reintegration, is more precarious than a fixed term contract which is covered during the entire period by this obligation. Moreover, a part-time contract is not in itself neither stable nor unstable, it all depends on whether or not art. 18 of the Workers Statute ${ }^{21}$ is applicable.

${ }^{18}$ See M. Tiraboschi, Contratto unico fuori dal tempo, journal article, in Sole 24 Ore, published on 12 april 2011.

19 See L. Mariucci, Le politiche del lavoro di fronte alla crisi, "Rivista Italiana di Diritto del Lavoro" 2009, III, p. 127 and ff.

${ }^{20}$ See F. Carinci, "Provaci ancora, Sam": ripartendo dall'art...

${ }^{21}$ Ibidem. 
Another criticism to the proposed reform is that it does not take into account different realities in the country and the variation of the labour market in different economic sectors and different geographical areas.

Above all, the dualism between insiders and outsiders, understood as a stark contrast between two heterogeneous blocks, where the boundaries between the two types of workers are very unstable and faded ${ }^{22}$, is not so clear. In this regard, the solution of challenges posed by the economy to the regulation of the labour market cannot be drawn from the neo-liberal teachings of law and economics, on the assumption that subtracting guarantees from workers increases the chances for the unemployed to find a job.

Moreover, considering the actual dynamics of the Italian labour market, this mechanism seems to be attractive only for medium-large enterprises of the North. They would gain the advantage of being able to hire young workers, without the constraints of real protection against unjustified dismissal.

Such criticisms do not look at the good news provided by the new single employment contract, as for what concerns, for example, the promotion of the concept of "economic dependence", the "absorption" of most forms of atypical work currently used by enterprises, and the consequent return of the limitation of temporary contracts.

What is certain is that the still dominant culture among Italian labour lawyers, at least the one expressed by the critical approach towards flexicurity, does not seem ready to accept solutions, which create a right of recourse to the stability of the workplace - symbolised by art. 18 of the Workers' Statute - in favour of new social, procedural and transactional rights.

According to Carinci, the attention to this single employment contract comes from the debate on Article. 18 of the Workers statute, as "the alternative of the single employment contract does not involve any permanent removal, but only a temporary de-activation of the reintegration procedure, promoted to the enterprises for all the new recruits who can count on a permanent contract. Moreover, such a contract does not concern the existing workers but only those who will enter the labour market, so it would not have an immediate impact, but would be scattered in time, making it difficult to imagine a real change in a short period of time ${ }^{\prime 23}$.

It is worth considering, moreover, that other legislative proposals seek to put into practice the idea of the single employment contract (in particu-

${ }^{22}$ See L. Mariucci, Le politiche del lavoro...: he takes Fiat as an example and points out that applying the dualistic setting, insider workers employed for an indefinite period would be identified, without taking into account the consequences that might occur if the company has to consider the CIG (Cassa Integrazione Guadagni) (redundancy found).

${ }^{23}$ See F. Carinci, "Provaci ancora, Sam": ripartendo dall'art..., p. 48. 
lar Bills n. 263/09 and n. 2000/10) by replacing the mechanism of judicial control of layoffs with measures of incentives (severance cost).

By declaring similar objectives of employment policy, the p.d.1. n. 263/09 on CUIF ("Contratto unico d'inserimento formativo", Single Entry Training Contract) and the d.d.1. n. 2000/10 on CUI ("Contratto Unico d'Ingresso", Single Entry Contract) provide for the introduction of a new contractual instrument, which is a candidate to become the typical form of recruitment employed by the same employer, absorbing the existing contractual figures and recomposing them in a single legal scheme. In fact, these proposals do not envisage the creation of a new legal type, but a "way or a path, easier to access, that can sum up in itself the advantages of flexibility and placing themselves in an alternative universe of atypical work" ${ }^{24}$. In the case of CUIF the elimination of many atypical contracts is expected (art. 2, para. 6, d.d.1. n. 2630/09), so the single employment contract is even an alternative to the contracts with training purposes; differently, the CUI, even if it is candidate to become the "typical" form of recruitment, does not change the rules in place. The effect of reductio ad unum is achieved through the CUI which is more attractive for the enterprise. It provides that "enterprises save money in investing in the workplace and allowing to keep it in the enterprise" 25 .

Elements of convergence emerge with reference to the underlying flexicurity philosophy for both projects, expressed, however, with less consistency and less "European" planning, compared with the Ichino proposal, especially as regards the strengthening of security measures in the labour market.

The bi-phase ${ }^{26}$ structure of the contractual scheme shows the logic of progressive stability, with an element of increasing protection against individual dismissals. In case of dismissal for economic reasons, the guarantees of stability are reduced while the security measures are stronger in the labour market.

In particular, compared with the forms of entry flexibility available today, the CUI provides workers with stronger protection, in form of redundancy payments compared to the duration of the relationship, where the CUIF provides a more strict regime dealing with the termination for justified reason (Article 6) and refers to labour market protections of a future reform of social security benefits (Article 10).

\footnotetext{
${ }^{24}$ In this sense see P. Tullini, Proposte di revisione..., p. 37.

${ }^{25}$ Relation to d.d.l. n. 2000/10.

${ }^{26}$ P. Tullini, Proposte di revisione...
} 
Even on these proposals, more timid than the Ichino's one, there have been some criticisms. On the one hand, it was argued that "it is not certain that the single employment contract will be for the employer equivalent to a fixed term contract [...] and why or how the worker may prefer this contract compared with a fixed-term contract with an appreciable duration, which could always be converted into a permanent contract"27.

On the other hand, the reservations concern the possible use of the single employment contract as an "escamotage" to overcome "the stiffness related to the stability of a real job", through a contractual scheme that, however, seems to be "reserved only for large segments of the economic system" 28 .

In this sense, Mariucci ${ }^{29}$ considers the adjective "single" as a really tempting adjective, but not the more suitable because, in reality, it represents an additional contract, and hence he suggests to better define it as a "prevalent" contract (in the sense of a dominant contract vis-à-vis the others). He points out two critical observations: firstly, that the American labour market, among the most liberalized in the world, has long been mentioned as a model; nonetheless, there are more unemployed (about 20 million) in the USA than in Italy; secondly that, considering the latest version of Ichino's proposals, in which art. 18 will not apply for new hires 186 leaving it unchanged for the already employed, this solution would introduce a new and unacceptable dualism between those who have already entered the labour market and those who aspire to enter.

On the contrary, the Italian Prime Minister Mario Monti ${ }^{30}$, criticising the current labour market dualism, supports the idea of a single employment contract, as it could guarantee a "real universal discipline" for the new workers. This has been taken up by the current Renzi's government, and the parliament is debating the introduction of the Jobs Act with its delegate decrees for the implementation, among others, of the single employment contract in the Italian system.

In this regard, it should be noted that the critical considerations are divided between a conservative evaluation and innovative points of view. These are also the terms of the debate on flexicurity as a comprehensive project of the labour market reform which requires a radical attitude by changing the trade-off between flexibility input and flexibility output, income protection and active labour market policies.

27 In this sense M. Magnani, Diritto dei contratti di lavoro, Giuffrè, Milano 2009, p. 171.

${ }^{28}$ See G. Ferraro, Tipologie di lavoro flessibile, Giappicheli, Torino 2009, p. 23.

29 See in this sense, L. Mariucci, L'analisi, journal article published in L'Unità, 5 January, 2012.

${ }^{30}$ See the Prime Minister Mario Monti's speech, Communication by Monti to the Senate, 17 November 2011. 


\section{The Proposal in France: "le Contrat de Travail Unique" (CTU)}

\section{The CTU Contract's Origins}

In France, the proposal of a single employment contract, that is an homogeneous contract of indeterminate duration for all workers, called "le contrat de travail unique" (CTU), is mainly aimed at eliminating the distinction between fixed term contracts (contrats à durée déterminée, CDD) and open ended contracts (contrats à durée indéterminée, CDI), in order to eliminate some of the problems of the labour market, such as the precarity, the duality between insiders and outsiders, the lack of personal support for the unemployed, the difficulty in perceiving the reclassification to ensure a professional future, and the general volatility of employment contracts.

This idea of a single employment contract has been proposed, by two couples of internationally recognized economists, Blanchard and Tiro$\mathrm{le}^{31}$, and Cahuc and Kramarz ${ }^{32}$. The debate on its possible introduction in the French legal system was launched during the President Nicolas Sarkozy's administration. In 2007, President Sarkozy, during the presidential campaign ${ }^{33}$, proposed the implementation of a single open-ended employment contract, with progressive rights, even if weaker as regards the dismissal for economic reasons ${ }^{34}$.

The advertised two economic reports were published a few years earlier: the Blanchard and Tirole's Report, which was presented to the Conseil d'analyse économique in $2003^{35}$, and the Cahuc and Kramarz's Report, in 2004, on professional social security. The aim of both proposals was principally to reduce the duality of the French labour market ${ }^{36}$. The economists pro-

31 See for details O. Blanchard, J. Tirole, Contours of Employment Protection Reform (November 1, 2003). MIT Department of Economics Working Paper No 03-35. Available at SSRN: http://ssrn.com/abstract=464282 or http://dx.doi.org/10.2139/ssrn. 464282 (12 February 2012) and the Italian version O. Blanchard, J. Tirole, Profili di riforma dei regimi di protezione del lavoro, "Rivista Italiana di Diritto del Lavoro" 2004, fasc. 2, parte I, pp. 161-211.

32 See for details P. Cahuc, F. Kramarz, Rapport au ministre de l'Économie, des Finances et de l'Industrie et au ministre de l'Emploi, du Travail et de la Cohésion sociale, 6 décembre 2004, Paris, "La Documentation française" 2005.

${ }^{33}$ See Projets - Actu. soc. n. 99/2007 du 16 avril 2007.

34 The idea was to protect "Moins les emplois et davantage les personnes, grâce à la création d'un contrat de travail unique, à durée indéterminée, à droits progressifs, plus souple en matière de licenciement économique". From M. Sarkozy's speech of 18 december 2006 in Charleville-Mézières.

${ }^{35}$ See O. Blanchard, J. Tirole, Protection de l'emploi et procédures de licenciement, "La Documentation française" 2003.

36 See P. Cahuc, F. Kramarz, Rapport au ministre de l'Économie, des Finances et de l'Industrie et au ministre de l'Emploi, du Travail et de la Cohésion sociale, 6 décembre 2004, Paris, "La Documentation française" 2005. 
posed a new single employment contract in order to limit the inequity due to the excessive utilisation of fixed term contracts, and to simplify the employment contract, as its progressive complexity was an important source of inequality of treatment for the last two decades.

In particular, Cahuc and Kramarz disapproved:

a) the very specific procedures regarding internal and external reintegration, which concerned undertakings in case of collective redundancies;

b) the lack of a research for an agreement between the employer and the workers about collective redundancies;

c) the delays related to the dismissal procedure;

d) the strengthening of the use of CDD since the early $90^{\prime} \mathrm{s}^{37}$.

\section{The Content of the CTU Contract}

This open-ended contract contains the role, the professional qualification and the wage of the employee, it could be ended by an employee's error, by agreement of both or by the closing of the activity for which the employee has been hired.

On the whole, this system will be characterised by two elements.

First, enterprises will be able to freely dismiss workers: the role of labour tribunals will be significantly reduced, no appeal against the firm's decision (except in case of discriminatory layoff). (In this sense the French reform is stronger than the one proposed in Italy because this means that there will not be a judicial control of dismissals).

Second, enterprises will have to bear the cost of their dismissal decisions: they will have to pay both a solidarity contribution to the State, in order to finance the insurance unemployment system (as they already do), and they will also have to pay an indemnity to the worker when the layoff takes place. Both the contribution to the State and the severance payment will be increasing according to seniority (Blanchard and Tirole) and will be proportional to the total pay received by the worker during the period of service (Cahuc and Kramarz). In addition, the latter suggest increasing the indemnity by a precarity bonus during the first eighteen months of service, in order to avoid the utilisation of short-term contracts. For example, in case of termination of the contract, the employer has the obligation to pay the employee an allowance called "precarious indemnity" (with less than 18 months of employment, the employer shall pay to the employee a redundancy equal to $10 \%$ of total wages received by the employee during the length of the contract) and he should help the employee in finding a job (helping him in preparing the CV and giving him some contacts). The employer is, then, required to pay a contribution

${ }^{37}$ See N. Mihman, Le contrat unique: une bonne idée?, "IUS Labor" 2007, 2. 
of solidarity to the State, which is used to finance the re-taking charge of the Class Transfer data from public employment services, which will be equal to $1,6 \%$ of gross wages paid to a dismissed worker for participating in the financing of such funds until the new job is entered. In this way, enterprises may avoid paying the solidarity contribution in case they offer a system of employment re-direction to dismissed workers, but an employee with less than 18 months of work does not enjoy such an employment safeguard ${ }^{38}$.

\section{The Comparison between the CTU and its Previous Attempts: the CNE and CPE}

The contrat de travail unique (CTU) easily recalls two failed French experiments. Earlier, the national legislator, in order to promote flexicurity, promulgated two different, but very similar, open ended contracts: the CNE (Contrat nouvelles embauches) and the CPE (Contrat première embauche): both of them were thought as open ended contracts, and stated the prohibition of firing a worker without a real and serious reason ("une cause réelle et sérieuse"), even if, in the initial trial period of "consolidation", this prohibition did not exist.

The new CTU is different from the old proposals for the following reasons.

The Contrat Nouvelle Embauche (CNE) is a contract introduced in France in 2005 that was abrogated in 2008. It was an open-ended contract, applicable only to enterprises with fewer than twenty (20) employees. The main characteristic of such a contract was its flexibility on the period of consolidation of two years, during which employers were allowed to fire at will and on a short notice, without the need to justify the dismissal, just because a hire "ad libitum" was permitted.

This CNE was used as a model for another contract proposal, the Contrat de Première Embauche (CPE), a contract that the French government tried (unsuccessfully) to introduce in 2006. The CPE was available solely to employees under 26 years old and was intended to encourage firms with more than 20 employees to hire "workers at risk", namely long term unemployed young people, belonging mostly to disadvantaged social groups. The CPE implied a trial period of two years during which, as the previous CNE, the employers could dismiss without the need to provide any justification. Due to protests from students and trade unions and the general public, the proposal was withdrawn. These contracts

38 See F. Lamyline, L'ANDRH ranime le débat sur le contrat de travail unique, Liaisons Sociales Quotidien - Liaisons Sociales, Bibliothèque: Bref sociale, Rubrique: études et rapports, 2011. 
aimed at overcoming the resistance of enterprises to hire with open ended contracts, in the sense that the enterprise was allowed to check at the beginning the real suitability of the worker, by not immediately binding itself to a permanent contract. Such a proposal was rejected at home, but got much interest abroad. It was called a "stillborn contract" 39 , and the CNE (in life from August 2005 to June 2008) was condemned by various decisions of French labour courts. The CNE was also considered by the ILO, in October 2007, as a legislative act contrary to the ILO Convention No. 158 ratified by France.

Both these contracts had a short life, so short that Flament and Sachs defined the CPE as "an unforgettable example of the law enacted that the head of the state officially calls not to apply"40, and the CNE as a "victim of a veritable infanticide", in a sense that as "soon as it was brought to the baptismal font, preparations for his funeral were already waiting" ${ }^{\prime 1}$.

\section{The Debate}

The CTU causes is today at the centre, a lively debate.

The main reason for this debate is clearly highlighted by Antoine Ly-

190 on-Caen, who, discussing the CTU project, said that "il n'est pas acquis qu'ils [the legislator and the trade unions] parviennent à s'accorder sur le projet de contrat unique et sur la sécurisation des parcours professionnels. Car aux racines de ce projet, il y a l'aspiration à organiser la fluidité sur le marché du travail, à y promouvoir une instabilité plus vigoureuse, alors que la sécurisation annonce, selon les organisations syndicales, un programme de réduction de la précarité" 42 .

On June 2011, the ANDHR (Association nationale des directeurs de ressources humaines) re-started the debate on the matter "pour lutter contre l'utilisation excessive des CDD et de l'intérim et [...] pour simplifier le Code du travail" ${ }^{43}$. The association, presided by Jean-Christophe Sciberras, the DHR of Rhodia's group, proposed the instauration of "un contrat de travail unique sans notion de durée ou de motif pour en finir avec la pré-

${ }^{39}$ See in this sense, L. Flament, T. Sachs, Simplifier le droit du travail?, "Revue de Droit du Travail, Dalloz" 2010, p. 489 "des dispositifs législatifs [...] son mort-nès..."

40 "Example inoubiable de loi promulguée que le chef de l'Etat appelle officialement à ne pas appliquer". See L. Flament, T. Sachs, Simplifier the droit...

41 "Victimes d'un véritable infanticide, tel le CNE: à peine était-il porté sur les fronts baptismaux que les préparatifs de son enterrement se faisaient déjà entendre". See L. Flament, T. Sachs, Simplifier the droit...

42 A. Lyon-Caen, Unité, simplicité, dialogue, "Revue de Droit du Travail" 2007, p. 1.

${ }^{43}$ M. Landré, Contre la précarité, les DRH prônent un contrat de travail unique, "Le Figaro", article publié le 16.06.2011. 
carité" 44 "a single employment contract without notion of duration or reason with a view to ending with the precarity" which concerns all young people, in the framework of a program of social dialogue implementation and young employment development. On that occasion, this proposal was submitted to the labour minister, Xavier Bertrand, who suggested studying the CTU proposal in order to substitute the actual CDD and CDI ${ }^{45}$.

Trade unions, on the contrary, were against such a proposal of a single employment contract because they saw a general precarity risk for the employment relationship. For example, the Force Ouvrière (FO) trade union considers the proposal a "flexibilité à outrance". The FO general secretary, Jean-Claude Mailly, believed that in order to give confidence to the youth, it is sufficient to introduce extra-curricular stages. This new single contract was also contrary to the ILO Convention on termination of employment (No 158) which requires a "motif réel et sérieux" to terminate the employment contract.

According to the Confédération Française des Travailleurs Chrétiens (CFTC), the CTU is a "fausse bonne idée", because it is a CDD with a non-defined end, which makes workers even weaker in an employment relationship, because this type of contract limits the dismissal procedures. CFTC suggested that, in order to combat precarity in professional transfers during the life time career, it was necessary to introduce a workers statute ${ }^{46}$.

Employers did not agree either with this proposal because they would not have clear advantages of choosing among so many different contracts that would better answer to their need of flexibility.

Most of the juridical doctrine is very critical of this proposal. Morvan, for example, criticizes this project because "it is enough to pay for dismiss $^{\prime 47}$ and he believes that the only objective of the CTU is to reduce the multiplicity of contract types, because the French social problems are not only due to the nature of the contract of employment, but to many other reasons ${ }^{48}$. As an alternative, he proposes a better use of CDI contracts. The legislator should facilitate the conclusion of an open ended contract relationship ("more firing, more hiring") and create an alternative dismissal procedure, offering to workers a greater indemnity facing the employer choice, which, if necessary, should be submitted to the judicial control.

44 Ibidem.

${ }^{45} \mathrm{M}$. Bartnik, Un contrat de travail unique difficile à mettre en oeuvre, "Le Figaro", article publié le 17.06.2011.

${ }^{46}$ See J. Freyssinet, Francia, l'accordo sulla modernizzazione del mercato del lavoro, "Eguaglianza e libertà, Rivista di critica sociale", 23.04.2008.

47 "Il suffit de payer pour congédier", P. Morvan, La chimère du contrat de travail unique, la fluidité et la créativite, "Droit Social”, novembre 2006, n 653, p. 960.

${ }^{48}$ See P. Morvan, La chimère du contrat de travail unique, la fluidité et la créativité, "Droit Sociale", n' 11, Novembre 2006. 
Antoine Lyon-Caen, defining the CTU as a "séduisante suggestion", reminds that fixed-term contracts have been introduced for serious reasons, which cannot be ignored:

"On ose à peine rappeler que le contrat conclu pour un temps limité ou une oeuvre déterminée n’a pas été inventé pour contourner les règles sur le licenciement et répond à des besoins profonds" 49 .

Someone else considers the Cahuc-Kramarz report as a real "déresponsabilisation totale des entreprises", because it transfers the obligation of re-classification of the worker to the public employment services ${ }^{50}$. Others point out the necessity to take into consideration, as for the CNE, the matter of compatibility with art. 4 of the ILO Convention No 158, which obliges the employer to have a good reason to fire a worker. This doubt has been stressed also by the Conseil d'Orientation pour l'emploi (COE), that, already in 2006, rejected the idea of a single employment contract, not only due to the problem of divergence from the ILO Convention No 158 but also to a series of perverse effects: The old CDD could became a sort of short-term contract; there would be a sort of judiciarisation of the termination of the employment relationship; each employee hired for a particular reason could protest against the reason of his dismissal; the elimination of the reintegration for the enterprises could lead to a preference to choose a quantitative and not a qualitative approach, based on competences and professions. For these reasons, according to the COE's opinion, a system of transition has to be provided, in order to go from the current contracts to a new juridical system, with a view to keeping the acquired rights. For the COE, the single employment contract should re-discuss all the recent legislative evolution in favour of a planned forecast management of employment and competences. In addition the COE suggests the creation of a bonus-malus system for enterprises, due to the dismissal and the temporary employment relationship they have: this contribution would be calculated on the total wages received by the enterprises' workers, and it could be regressive, with a view to incentivising employers to keep their workforce. According to Kramarz, the bonus-malus system is justified by some economic reasons: "lorsqu'une entreprise décide de licencier un salarié, elle ne prend pas en compte le coût infligé à la communauté (chômage, pertes de liens sociaux pour la personne licenciée). Ce coût est une externalité négative. La mise en place d'un bonus-malus proportionnel (par exemple) à l'ancienneté du salarié payé à l'agence pour l'emploi permet à l'entreprise $\mathrm{d}^{\prime}$ «internaliser» ce coût $\mathrm{t}^{\prime 51}$.

49 See A. Lyon-Caen, Unique, "Revue de Droit du Travail” 2007, p. 421.

${ }^{50}$ See in this sense prof. Antonmattéi, Le contrat de travail unique est-il souhaitable? Lamyline. fr. Semaine Sociale Lamy, 4.01.2012.

${ }^{51}$ F. Kramarz, A. Lyon-Caen, Questions sur l'accord du 23 janvier sur la modernisation du marché du travail, "Revue de Droit du Travail" 2008, p. 146. 
This new form of financing could be balanced by a smaller unemployment contribution, by reducing the labour $\operatorname{cost}^{52}$.

Not all the doctrine is so sceptical. Lagarde and Jeammaud, for example, consider the idea of a CTU "plutôt une bonne idée": starting from the consideration that "the law doctrine, following Montesquieu and Portalis, do not have a sympathy for uniformity", because the employment contract has to be modelled in most of the cases, they consider the different attractions for the CTU, under different profiles: politics, moral (more equity between insider and outsider workers), social and economic (many economists affirm that in order to combat unemployment, it is necessary to concentrate on the labour market's fluidity, which is more useful than fighting dismissals ${ }^{53}$.

\section{Labour Market Situation}

The situation of the labour market in France is similar to the Italian one. On average, out of the OECD countries, the $75.9 \%$ of the young employed benefit from a permanent job, in the hexagon this rate drops to $47.8 \%$, and the crisis worsens this situation of precarity and young unemployment ${ }^{54}$. In France, as well as in other countries such as Italy and Spain, the portion of a stable employment is one of the weakest. Cahuc and Kramarz pointed out in their report that more than $70 \%$ of employment contracts are fixed term contracts, and more than the $50 \%$ of them are not converted, at the end, in open-ended contracts.

As we have said above, the CTU could be a possible solution. Yet, it is not the only one and it would not be of a simple and fast application. In fact, it is of vital importance to evaluate the impact that a single employment contract would have on the whole system. It concerns the current employment contracts, the transfer from an old contract to a new one, the renewal of the unemployment insurance system, and the development of a real social dialogue with the trade unions to define a precise content of the contract, including the provision of limits to the employer's dismissal power, which should continue to be subject to the judicial control.

In truth, the labour market dualism is one of the most serious problems in France, but not the only one. The CTU could be, in this sense, a possible path to follow, but it has to be accompanied by a wider reform,

${ }^{52}$ See F. Lamyline, Un prérapport du COE rejette l'idée du contrat de travail unique, Liaisons Sociales Quotidien - 2006, Liaisons Sociales, Bibliothèque : Bref Social, Rubrique : études et rapports.

${ }^{53}$ See X. Lagarde, A. Jeammaud, Que penser du "contrat de travail unique"?, "Revue de Droit du Travail" 2007, p. 8.

${ }^{54}$ See M. Bartnik, Un contrat de travail unique... 
based on a fundamental reconsideration of the crucial role played by enterprises in sustainable development, which cannot wait the next generation of workers.

As pointed out by Cahuc and Kramarz, in order to obtain the goal of a career security, the development of the employment contract and the regulation of dismissal must be based on two complementary principles: a) the recognition of the social value of the employment and protection of the persons, and b) the implementation of the right to workers' reclassification. The authors contrast the social value and the value of the private employment. The former is the value of a job for the community, that is the impact of the destruction of a job; the latter is the production of goods and services by a worker, that is divided into pay for the worker and profit for the enterprise. The difference between the two values is measured by the loss of tax and social transfers induced by the change of status of a worker from employed to "being unemployed or inactive" For this reason, it is important to consider the social value of the job, taxing the dismissal that gives to the State an obligation of insurance unemployment that is paid by the community.

Moreover, the elimination of all the different types of contracts would mean to neglect all the last decades of labour law that led to different em-

194 ployment contracts solutions (part-time, contrat de mise à disposition, contrat de mission, travail temporaire, travail à temps partagé, contrat unique d'insertion, contrat d'apprentissage, etc.), which were requested by the market, in order to answer to flexibility, which was thought to be useful to growth of the labour supply with a view to helping the weakest parties of the labour market. Such a need of flexibility is still there.

It is probably the moment for an important reform in the French labour market, and if the debate about the CTU could be a tool to find a solution, it is worth to continue it.

\section{The Debate in Spain on the Single Employment Contract}

\section{Context}

In Spain, the topic of the single employment contract was introduced in the labour law doctrine debate by the Fundación de Estudios de Economía Aplicada (FEDEA), in 2009, a foundation supported by 100 economists, which proposed a single permanent employment contract: the idea was to promote a new single employment contract of indefinite duration for all new recruits, with a cost of dismissal progressively

${ }^{55}$ See N. Mihman, Le contrat unique... 
based on the seniority of the employee, from 8 days of wages per year up to a maximum located between 20 days and 45 days of wages per year.

This single type of contract that involves a radical change in the labour relations model in Spain, affects two of its key elements, such as the existing regime on recruitment and the dismissal model. In fact, such a measure would involve, first, the elimination of fixed-term contracts and, simultaneously, the elimination of the existing system of dismissal, unifying hiring and firing discipline, without distinction between the individual and the corporate layoffs or between a fair or an unfair dismissal. Thus, judicial review would be limited, only, to layoffs due to violation of fundamental rights and disciplinary dismissal without compensation with a recognized possibility to appeal by the worker.

The debate on the single employment contract follows more or less the same trends in countries such as France and Italy. However, Spain has a major factor of pressure, due to the high levels of unemployment. In fact, recent rates from the last population survey (EPA) - January 2012 - credited the number of unemployed people to 5.27 million of unemployed, representing a rate of 22.8 per cent of the workforce. Clearly it is a negative development that materializes also when disaggregated rates on youth unemployment, causes of a long-term exclusion, with a certain number of families without a wage or an unemployment insurance, are analysed. Some data are also reported by the ILO Report Global Employment Trends $2012^{56}$, where there is a 10 per cent of the total of 27 million jobs lost since the beginning of the economic crisis - that means 2.7 million new unemployed - belong to Spain. The report also reflects some other alarming rates, such as a 48 per cent youth unemployment in the age of 25 years, compared to the 12 per cent in the rest of the world.

However, the size of the unemployment rates, certainly unacceptable for any country, cannot affect all legal keys after a debate of this nature, about the suitability or the unsuitability of a single employment contract. That is, the solution must fit the labour legal system, considering also the references to the constitutional order, as well as international and EU standards.

\section{Reasons for the Debate on the Introduction of a Single Employment Contract}

The debate in Spain, about the possible introduction in the legal system of a single employment contract, places itself in the middle of the path between the problems of the dual model of temporary contracts and unfair

${ }^{56}$ See ILO, Global Employment Trends 2012, ILO, Geneva. 
individual dismissals, on the one hand, and the virtuality of the single employment contract itself, as a key solution of some structural problems that characterize the Spanish model of labour relations, on the other hand.

\section{The Dual Model of Fixed Term Contracts and Unfair Individual Dismissal}

Among the reasons given against the introduction of the single employment contract, with an increasing firing cost depending on the worker's seniority, regardless of what their final content is, there is a criticism based on the existing framework of the wrong hiring and dismissal discipline.

Indeed, in the Spanish model of labour relations, enterprises channel the unilateral termination of employment mainly through two ways:

a) the temporary flexible contracting of articles 15.1 and 49.1.c of the Workers' Statute, primarily, through the use of two types of temporary contracts such as "los contratos de obra y servicio determinado" (Article 15.1.a), and "los contratos eventuales por circunstancias de la producción" (Article 15.1.b). These are contractual arrangements that allow easy termination of employment with a minimum charge of 8 days' salary

196 per year worked.

b) individual unfair dismissal provided under Article 56.2 of the Workers' Statute, as amended by Law 45/2002 of 12 December 2002, "de medidas urgentes para la reforma del sistema de protección por desempleo y mejora de la ocupabilidad", allows the enterprise to recognize the unfair dismissal, and then to make available to the worker either 33 days per year of service or 45 days per year of service, depending on the type of the permanent contract in question.

The problem pointed out by the doctrine concerning this dual system for the unilateral termination of an employment contract, lies in the quantitative difference on each of the options listed in one case, 8 days of salary per year of work, and in the other case, either 33 days per year of service or 45 days per year of service, according to the type of open ended contract $^{57}$.

In this regard, such a regime provides another additional dysfunction, notably the facilitation of individual dismissals, avoiding in this way the trade union bargaining power and the judicial control of business decisions $^{58}$.

${ }^{57}$ See J. Lahera Forteza, Elogio y crítica jurídica a la propuesta del contrato de trabajo único, "Relaciones Laborales" 2010, núm. 1, p. 121.

${ }^{58}$ See M. Rodríguez-Piñero, Sobre el contrato de trabajo único, "Relaciones Laborales" 2009, núm. 10, p. 8. 
Meanwhile, the current dismissal model also generates a third problem, such as the marginalization of redundancy for business-economic, organisational, technical and production- reasons of articles $52 \mathrm{c}$ ) and 51 of the Workers' Statute, for which a compensation of 20 days salary per year is provided.

Such a dismissal model would be even suitable for use where there is reason to perform job settings. In practice, these are very marginal cases, before the massive use of temporary precarious contracts, (contrato de obra o servicio determinado - article 15.1.a) of the Workers' Statute and the contract for some production circumstances (Article 15.1.b) of the Workers' Statute.

All this raises questions on how best to apply a complex configuration of the procedures for termination of business. For example, in relation to the test that the employer is to be submitted to in order to prove the situation that justifies the dismissal, it would ease the margins of uncertainty for the enterprise.

\section{The Single Employment Contract as a Solution}

The key discussion is to see what solutions can be applied to the current situation. This is where the debate on the single employment contract enters, and with it, the positions of in favour or against it, in relation to its legal viability.

As far as arguments against the introduction of the single employment contract are concerned, the doctrine appeals basically to the constitutional perspective, especially Articles 14, 24.1 and 35.1 of the Spanish Constitution; the possible violation of ILO Convention No 158; and article 30 of the European Charter of Fundamental Rights.

\section{The Constitutional Perspective}

Regarding the constitutional perspective, it has been noted that, firstly, there is a possible collision between the single employment contract and the principle of equality under article 14 of the Spanish Constitution, as the new contract is reserved only "for all new hires" ("para todas las nuevas contrataciones") $)^{59}$. So that there would be a different regulation, unconstitutional, between employees already in the labour market and future ones, which enter the labour market after the introduction of the single employment contract.

59 See J.M. Goerlich Peset, ¿Contrato único o reforma del despido por causas empresariales?, “Relaciones Laborales" 2010, núm. 1, p. 78-79. 
Secondly, it has been pointed out that there is a possible violation of Article 35.1 of the Spanish Constitution, comprehensive of an express recognition of the labour law, when it states literally that "Todos los españoles tienen el deber de trabajar y el derecho al trabajo, a la libre elección de profesión u oficio, a la promoción a través del trabajo y a una remuneración suficiente para satisfacer sus necesidades y las de su familia, sin que en ningún caso pueda hacerse discriminación por razón de sexo."

In particular, the Constitutional Court in its judgment No 20,1994 of 27 January 1994 stated that the substance of the right to work includes the right to job security, as far as saying that "la inexistencia de una reacción adecuada contra el despido o cese debilitaría peligrosamente la consistencia del derecho al trabajo y vaciaría al Derecho que lo regula de su función tuitiva, dentro del ámbito de lo social como característica esencial del Estado de Derecho (Article 1 of the Spanish Constitution)" ${ }^{\prime \prime 0}$.

Thirdly, it has been noticed that there is a possible violation of Article 24.1 of the Spanish Constitution, in the case of establishing the single employment contract, considering that one of its main objectives is to eliminate the judicial review of the dismissal, except dismissals based on discriminatory reasons, thus providing, in this way, security and certainty to enterprises' dismissal decisions, and the enterprise should know

198 the costs of a dismissal ${ }^{61}$.

Of all the objections outlined above, the doctrine advances a particular difficulty regarding the principle of equality (Article 14 of the Spanish Constitution). The introduction of the single employment contract, even if it substantially altered the mechanisms for ensuring stability in existing employment, it could not be argued that it would carry a total lack of protection of workers ${ }^{62}$.

\section{The Framework of International and European Union Legislation}

At the same time, the proposal of a single employment contract has been submitted to a labour law review process, with reference to international and EU labour standards.

With respect to international labour standards, the adoption of this type of contract in the law contrasts with the provisions of ILO Convention $\mathrm{n}$. 158, so that regardless of which will be ultimately the terms of their

${ }^{60}$ See J.M. Goerlich Peset, ¿Contrato único..., p. 78-79; J. Lahera Forteza, Elogio y crítica jurídica..., p.123-125.

${ }^{61}$ J.M. Goerlich Peset, ¿Contrato único..., p. 79.

${ }^{62}$ Ibidem, p. 80-84. 
specific regulation, unification of the regime of the dismissal causes, with the sole exception of those which are discriminatory or prejudicial to the fundamental rights, is not consistent with the terms of such a Convention which states the need for a legitimate cause for termination of employment by the employer, and it provides different legal effects for each cause of dismissal.

That is, as we have seen above, ILO Convention No. 158 distinguishes three levels of protection against termination of employment. This, with the conviction that the employer who dismisses a worker cannot do so in a capricious or manifestly arbitrary way ${ }^{63}$. Furthermore, in relation to the obligations under EU rules, the doctrine stated that the application of Directive 98/59/EC on collective redundancies, as for the definition of what is meant by collective redundancies, incorporates a distinction between the reasons inherent to the worker and those who are not (-a) and b) of Article 4.1. Directive 98/59/EC), which is the main difficulty in the case of collective redundancies, for the implementation of the single employment contract ${ }^{64}$.

In short, the unification of the amount provided for damages from dismissal, resulting from the implementation of the single employment contract, does not concern the causes for dismissal, ignoring the different grounds and the different features covered by compensation and indemnity related to the termination of employment ${ }^{65}$.

For some critics, the single employment contract does not guarantee a job security: it could even reduce it, increasing the employees turnover or could strengthen it, in the event that companies use layoffs as a mechanism to proceed with the replacement of workers. All aspects that, once verified, would have a negative effect in a more generalised job insecurity. In this regard, it would be possible to have a situation characterised by indefinite contracts subject to a legal regime of unfair dismissal with an expected lower compensation than those currently in force ${ }^{66}$. Faced with possible negative consequences in relation to a possible introduction of a single employment contract, the doctrine itself has also underlined some positive elements that may arise as a result of its future implementation. For example, the possible contribution to bring together the material reality with the formal reality, considering the recruitment without causes and the dismissal with legitimate reasons. The single employment contract may be considered a factor contributing to the rationalisation of dismissal costs and influencing

${ }^{63}$ J.M. Goerlich Peset, ¿Contrato único..., p. 86-87.

${ }_{64}$ M.C. Rodríguez-Piñero Royo, Algunos aspectos jurídicos de la propuesta de contrato único, "Relaciones Laborales" 2010, núm. 1, p. 111-112.

${ }_{65}$ M. Rodríguez-Piñero, Sobre el contrato..., p. 11.

${ }^{66}$ Ibidem, p. 11-12. 
generalisation of open-ended contracts, as well as a hypothetical revitalisation of fundamental rights ${ }^{67}$. However, in the Spanish context, the single employment contract fails to cover important risk factors. For example, there is a need to further explore aspects dealing with the duality - difficult to overcome - between the redundancies resulting from a worker's behaviour and those dismissals for business reasons; the need to integrate the procedures for collective redundancies with a stronger participation in the enterprise; an expected increase in litigation over the basis of the discriminatory dismissal or of the fundamental rights; the possibility of a new labour market segmentation between workers with open-ended employment contracts before and after the introduction of the single employment contract, and those, future workers, which could have this new contract; and finally, the risk of a widespread insecurity ${ }^{68}$.

\section{A Lively Debate}

As we have seen above, there is a lively debate in the legal doctrine on the possible introduction, in the Spanish legal system, of the single employment contract. A debate, particularly strong in Spain, as a result of high unemployment rates.

However, the problems inherent in employment policies, with high rates of unemployment, cannot ignore a rigorous legal analysis of the single employment contract vis-à-vis the constitutional principles (Articles 14, 24.1 and 35.1 of the Spanish Constitution), the international framework (ILO Convention No 158), and the European Union labour law (Directive 98/59/EC on collective redundancies).

All elements that question, seriously, the suitability of a possible adoption of the single employment contract in the Spanish labour regulations, especially as regards hiring and firing. The majority of labour lawyers see undesirable effects due to a further dual model of fixed-term contracts and open-ended contracts, and the risk of a widespread use of unfair individual dismissals.

\section{A Comparative Overview: Contractual Arrangements in EU Labour Markets}

In order to better understand the logic of the above mentioned proposal, and in view of further analysing the aspects around the introduction of the single employment contract, it would be worthwhile to give

${ }^{67}$ J. Lahera Forteza, Elogio y crítica jurídica..., p. 125-127.

${ }^{68}$ Ibidem, p. 127-136. 
a comparative overview of the current contractual arrangements in the EU Member States, albeit in a succinct manner.

The following topics have been taken into account:

1. Protection for all workers against lay-off at will, by forms of legal and/or monetary protection;

2. Clarity about this protection from day one of the contract;

3. A build-up of these protection rights continuously with job tenure;

4. No ex-ante time limits in contracts;

5. Sufficiently long entry phase followed by a stability phase.

Typically, many contractual arrangements are available in labour markets. However, the focus of the current discussion is on contracts that could be considered as "mainstream" contracts, serving around 95\% of labour/ employment relations. The following does not take into account for example seasonal fluctuating work or independent highly skilled and specialised "self-employed" contracted work.

In most labour markets, these main stream contracts include "open ended" contracts (also known as "permanent" contracts), "temporary contracts" ${ }^{69}$ and "labour market insertion contracts"70. For these contracts, information is needed on:

1. The build-up of protection rights; and

2. The cost structures in terms of social security contributions and tax treatment. This will shed light on labour market segmentation and to which degree it may be caused by existing contractual arrangements. Furthermore, it will allow the Employment Committee to better organise the discussion on whether these contractual arrangements can deal with the pressing call for more labour market flexibility.

According to the available information, the most common form of employment contracts in the EU-27 is the open-ended contract or the contract of indefinite duration. Where figures are available, the percentage of workers employed under such contracts generally ranged from high in Lithuania $(98 \%)$ and Cyprus (87\%) to much lower percentages in the Netherlands $(66 \%)$, and Portugal (61\%). Because these figures were taken from the total labour force including the "self-employed" they are lower than EUROSTAT figures which do not include these. Experts suggest that EUROSTAT (without self-employed) figures are consistently higher. One can safely conclude that all other reported percentages of workers employed under open-ended contracts would similarly fall if a more expansive view was taken of what constitutes the labour force.

${ }^{69}$ Temporary contracts are contracts which will be valid for a fixed period of time only.

${ }^{70}$ Labour market insertion contracts are temporary contracts but with a specific aim to lead to an open ended or permanent labour contract at its termination, if both parties so wish. 
The most significant other form of employment contract reported was that for a fixed term or for a definite duration. Where specific figures were provided, the percentages of persons employed under such contracts ranged from 18\% (Portugal) to 4\% (Belgium). Other reported forms of employment contracts include apprenticeship contracts (Austria, Ireland, Italy, Luxembourg), marginal employment contracts (Austria), free-lance contracts (Austria), temporary agency work contracts (Austria, Estonia, Ireland, Netherlands), project contracts (Italy), seasonal employment contracts (Greece, Hungary, Luxembourg), employment initiation contracts (Luxembourg), labour market insertion contracts (Portugal) and work performance/activity contracts (Slovakia). Some of these contracts - such as project contracts and work performance/activity contracts - clearly involve what elsewhere is described as "self-employed" and consequently falls outside of the scope of statutory employment rights and collective agreements.

\section{Types of Protection Offered}

A trial or probationary period is the period at the beginning of an employment contract - whether open-ended or fixed term - during which both parties (but invariably the employer) have the possibility of examining whether the job or the way it is being performed meets their expectations. If the contract is terminated during the trial period, invariably the worker enjoys less protection. So, in Austria, for example, termination of the employment contract is possible during the trial period without any notice period and without giving any reason. In some cases (Belgium, Cyprus, Czech Republic, Malta, Spain), the inclusion of a trial period in an employment contract is mandatory but its length can be determined by the parties to the contract. Only in the Czech Republic there is a mandatory fixed trial period ( 3 months). In most countries, the inclusion of a trial period in the contract is optional with lengths determined by contract parties. The table provides an overview of the wide variation found in probationary periods across the EU.

The position in Ireland and the United Kingdom is different in that, although the parties to an employment contract are free to decide whether a trial period should be included, and if so of what length, protection against unfair dismissal only applies after a certain period of consecutive employment. At present, this is 12 months in both countries increasing with effect from April 2012 in the UK to two years. In most countries, it is found that, where applicable, trial periods apply equally to fixed term contracts as they do to open-ended contracts. 
The European Debate on the Single Employment Contract

\begin{tabular}{|l|l|}
\hline \multicolumn{1}{|c|}{ Mandatory trial period in contract } & \multicolumn{1}{c|}{ Optional trial period } \\
\hline $\begin{array}{l}\text { Variable length, decided by contract parties } \\
\text { (Belgium, Cyprus, Malta, Spain) }\end{array}$ & $\begin{array}{l}\text { Short trial periods: } \\
\text { One month maximum (Austria, Denmark, } \\
\text { Belgium) } \\
\text { Two months max (the Netherlands) }\end{array}$ \\
\hline \multirow{3}{*}{$\begin{array}{l}\text { Fixed length (the Czech Republic, three } \\
\text { months) }\end{array}$} & $\begin{array}{l}\text { Medium length trial periods: } \\
\text { Three months max (Latvia, Lithuania, Poland, } \\
\text { Portugal, Slovakia) } \\
\text { Four months max (Greece, Finland) }\end{array}$ \\
\hline & $\begin{array}{l}\text { Long trial periods: } \\
\text { Six months max (Bulgaria, Germany, Hungary, } \\
\text { Italy, Luxembourg, Malta, Romania, Spain, } \\
\text { Sweden) } \\
\text { Even longer (Cyprus 24 months) }\end{array}$ \\
\hline
\end{tabular}

If conclusions are to be drawn, it must be that trial periods vary immensely across EU labour markets, between one and 24 months, but also within individual countries because in most countries the inclusion of trial periods is open as an option to contract parties.

A notice period is the period which either party must give in order to terminate an employment contract. The minimum period for open-ended contracts ranges from one week (Cyprus, Ireland, Malta, United Kingdom) to three months (Belgium, France-both as regards "white collar" workers). In a significant number of cases (the Czech Republic, Denmark, Greece, Germany, Hungary, Latvia, Lithuania, Malta, Poland, Portugal, Romania, Spain, Sweden), it is reported that identical periods apply in the case of fixed term contracts. However, in some cases (Austria, Belgium, Cyprus, Luxembourg) the relevant notice period is not applicable to fixed term contracts.

\section{Different Protection for "blue collar" and "white collar" Workers}

The type of protection offered to workers under open-ended contracts varies in some countries depending on whether the worker is regarded as being "blue collar" or "white collar" (Austria, Belgium, Denmark, France, Portugal, Romania). This impacts, for instance, the length of the trial period. In Belgium, for a blue-collar worker the trial period varies between 7 and 14 days, whereas for a white collar worker this varies from one to twelve months depending on salary levels. In Austria, the length of the notice period depends on job tenures and ranges from 6 weeks to 5 months for white collar workers, while blue-collar workers not serving under a collective labour agreement, are protected by a notice period of two weeks only. 
In a number of the countries mentioned above, labour market segmentation is reported between "blue collar" and "white collar" employees.

In all EU member States, employees on open-ended contracts are protected by unfair dismissal legislation; in some countries (Cyprus, Denmark, France, Germany, Ireland, United Kingdom) this holds only after a qualifying period of employment has been served. As regards employees on fixed-term contracts, it was found that this legislation did not apply only for Cyprus; with France and the Netherlands reporting that unilateral termination of such a contract was not possible. However, in Italy it is found that the average length of labour trials and the uncertainty about their outcome (which, in larger firms, might lead to a re-integration of the dismissed worker) in many cases provide employers with an incentive to hire on a temporary basis.

A statutory severance pay system for employees on open-ended contracts exists in almost all countries (with the exception of Finland, Romania and Sweden). Employees on fixed term contracts are hardly or not protected by severance pay systems in a range of countries (Belgium, Cyprus, Denmark, Finland, Italy, Lithuania, Luxembourg, Netherlands, Portugal, Romania, Spain and Sweden). This is a clear difference which provides incentives to firms influencing their choice between con204 tract types offered.

The nature and the extent of statutory severance pay systems vary considerably. For all countries (with the exception of the Czech Republic and Romania) it is reported that job protection rights build up with job tenure. Generally this principle applies to the amount of severance pay (not in Malta) and the length of the notice period (not Bulgaria, Finland, France, Italy, Latvia, Lithuania, Spain).

It is a relevant question whether this build-up of protection rights in job tenure is smooth or discontinuous. The way entitlements to severance pay build up may influence firms hiring/firing decisions and whether workers' contracts are continued and made permanent after their trial periods. In the Czech Republic, Poland, Portugal and Spain, it was indeed reported that such decisions are affected or influenced by contractual protection rights.

On a more positive note, the assessment of some of the independent experts concludes that the build-up of protection rights does not influence either the hiring or firing decisions of firms or influence their choice of contracts offered to workers (for example in Bulgaria, France, Germany, Hungary, Latvia, Malta, the Netherlands, Slovakia). If and when these findings can be confirmed, for these countries contractual arrangements may be ruled out as potential source of labour market segmentation. 


\section{Different Protection for Public Sector Employees}

In Slovakia and for public sector employees in Spain, holiday entitlements for employees on open- ended contracts increase according to length of service. There are other specific forms of protection for public sector employees originating from their contractual arrangements. In Greece, for example, employees in the public sector enjoy firm job security, while also pension entitlements and job promotion practices are based exclusively on job tenure. In Cyprus, employees in the private sector are not as well paid and enjoy clearly lower levels of job security than public sector employees and those working for utility and natural monopoly firms (electricity, water and communication sectors).

Elements like these may well cause segmentation between employment in the public sector and in the private sector.

\section{Incentives to Convert Temporary Contracts into Open-ended Contracts}

In some countries, there are provisions which generate incentives for firms to convert temporary/labour insertion contracts into open-ended contracts, this being the case, for example, in Italy, Luxembourg and Spain. Italy, for example, has seen various programs aimed at firms hiring workers in permanent contracts. In 2000 a program subsidised firms with almost 5,000 euro per year upon hiring permanent staff. It was discontinued in 2006 because of lack of funding and allegedly considerable deadweight losses; the firms that were mainly subsidised were those which would have hired permanent staff even without a subsidy. As of September 2011, the program has been reinstated again. Additional requirements are now included however; the worker needs to be a parent younger than 35. Firms are allowed a subsidy for a maximum of five new permanent hires. These incentives may well be needed given the low probabilities that workers in these countries have of moving from a temporary contract to an open-ended contract.

\section{Cost Structures to Provide Financial Incentives in Contract Type Choice}

Different cost structures typically do not provide financial incentives to workers and employers regarding their choice for one contract type or the other (Austria, Belgium, Bulgaria, Cyprus, the Czech Republic, Denmark, Estonia, Greece, Finland, Germany, Hungary, Ireland, Latvia, Lithuania, Luxembourg, Malta, the Netherlands, Poland, Romania, Slovakia, Sweden, United Kingdom). Denmark, however, draws attention 
to the use of "one-man firms" especially in the construction sector. By hiring an individual as self-employed, the employer can avoid following employment protection provisions, social security provisions, and collective agreements. This point may also be an issue in the Czech Republic, Germany, Estonia, Greece, Ireland, Hungary, Lithuania, Poland and Slovakia.

Only in Italy (explicitly) and Spain (implicitly) different costs structures in terms of social security contributions represent an important financial incentive for employers to hire under contractual arrangements with lower costs.

\section{Concluding Remarks}

The above topic needs further research and information gathering before coming with a solid and comparative solution whether or not it is necessary to introduce the single employment contract in a number of EU Members States. For sure, there are still questions to be answered, notably:

I. Is the single employment contract the solution to the problem of labour market segmentation?

II. Are there other major features relative to contractual arrangements that would need further analysis with a view to measure their impact on segmentation?

III. How can the available contractual arrangements in the EU Member States contribute already to reducing labour market segmentation?

These and many more questions would need to be answered in the near future.

\section{Bibliography}

Casale G., Perulli A., Towards the Single Employment Contract: comparative reflections, Hart Publishing, Oxford, ILO, Geneva 2014.

ILO, Global Employment Trends, Geneva 2013.

Casale G., The Employment Relationship: a comparative overview, Hart Publishing, Oxford, ILO, Geneva 2011.

Lyon-Caen A., Un nouveau songe?, "Revue de Droit du Travail” [Paris] 2010.

Boeri T., Galasso V., Un nuovo contratto per tutti, Chiarelettere, Milano 2008.

Lagarde X., Jeammaud A., Que penser du contrat de travail unique ?, "Revue de Droit du Travail" [Paris] 2007.

Valdes Dal-Re F., Zufiaur Narvaiza J.M., Hacia un mercado europeo de empleo, Ministerio del Trabajo y Asuntos Sociales, Centro de Publicaciones, Madrid 2006.

Cahuc P., Kramarz F., De la précarité à la mobilité: vers une sécurité sociale professionnelle, La documentation française, Paris 2004.

Perulli A., Economically Dependent/Quasi-subordinate (Parasubordinate) Employment: Legal, Social and Economic Aspects, European Commission, Bruxelles 2003. 
The European Debate on the Single Employment Contract

\section{Europejska debata o jednolitej umowie o pracę}

\section{Streszczenie}

Niniejszy tekst prezentuje porównawcze spojrzenie na różne formy umów o pracę i na sugestywną ideę stworzenia jednolitej umowy o pracę. Autor naświetla jej zalety i jednocześnie odkrywa wewnętrzne sprzeczności. Ukazuje także ogólne prawne tło obecnej debaty w tym zakresie i rysuje jej źródła. Rozważa też różne doświadczenia w takich państwach, jak Francja, Włochy i Hiszpania, przygląda się rozwiązaniom w odniesieniu do umów w innych państwach Unii Europejskiej oraz wskazuje możliwe rozwiązania i kierunki rozwoju rynków pracy.

Tłumaczenie z języka angielskiego - Zbigniew Hajn 